\begin{tabular}{|l|l|l||}
\hline \multicolumn{2}{|c|}{ PublisherInfo } \\
\hline \hline PublisherName & $:$ & BioMed Central \\
\hline \hline PublisherLocation & $:$ & London \\
\hline \hline PublisherImprintName & $:$ & BioMed Central \\
\hline \hline
\end{tabular}

\title{
Double mutations
}

\begin{tabular}{|l|l|l||}
\hline \multicolumn{2}{|c|}{ ArticleInfo } \\
\hline \hline ArticleID & $:$ & 4277 \\
\hline \hline ArticleDOI & $:$ & $10.1186 /$ gb-spotlight-20011214-01 \\
\hline \hline ArticleCitationID & $:$ & spotlight-20011214-01 \\
\hline \hline ArticleSequenceNumber & $:$ & 348 \\
\hline \hline ArticleCategory & $:$ & Research news \\
\hline \hline ArticleFirstPage & $:$ & 1 \\
\hline \hline ArticleLastPage & $:$ & 2 \\
\hline \hline & & RegistrationDate : 2001-12-14 \\
ArticleHistory & $:$ & OnlineDate $2001-12-14$ \\
\hline \hline ArticleCopyright & $:$ & BioMed Central Ltd2001 \\
\hline \hline ArticleGrants & $:$ & \\
\hline \hline ArticleContext & $:$ & 130592211 \\
\hline \hline
\end{tabular}




\section{Jonathan B Weitzman}

Email: jonathanweitzman@hotmail.com

The vast majority of genes in the yeast genome are non-essential suggesting significant functional redundancy. In the December 14 Science, Tong et al. describe an approach for high-throughput synthetic-lethal analysis in yeast (Science 2001, 294:2364-2368). They developed an ordered array of about 4,700 viable gene-deletion mutants and generated haploid double-mutants; they called this strategy synthetic genetic array (SGA) analysis. Tong et al. tested a query strain with a deletion in the $B N I 1$ gene against the ordered array and identified 67 potential synthetic lethal/sick interactions; these included known and novel interactions. Multiple SGA analysis allowed them to construct a large genetic interaction network containing over 200 genes. These interactions should identify functionally related genes and provide a framework for future phenotype analysis and probing the relationships between interacting pathways. The authors suggest that 300 SGA screens could provide an effective genetic scaffold to explore redundancy and genome buffering.

\section{References}

1. Principles for the buffering of genetic variation.

2. Science, [http://www.sciencemag.org] 